Energy Research Journal 1 (1): 26-31, 2010

ISSN 1949-0151

(C) 2010 Science Publications

\title{
Bioethanol Production from Rice Straw
}

\author{
Nutawan Yoswathana, Phattayawadee Phuriphipat, \\ Pattranit Treyawutthiwat and Mohammad Naghi Eshtiaghi \\ Department of Chemical Engineering, Faculty of Engineering, Mahidol University, Thailand
}

\begin{abstract}
Problem statement: Rice straw has been treated with different chemical (acid, alkali) and physical (subcritical water, ultrasound) methods to convert lignocellulose material to sugar. In addition enzyme treatment of pretreated samples has been applied to improve the conversion of lignocellulose material in sugar. Approach: Sulfuric acid at concentration of 1-9\% was applied for acid treatment. For alkali treatment was sodium hydroxide solution at concentration of 1-5\% used. Subcritical water treatment carried out at $160^{\circ} \mathrm{C}(5 \mathrm{bar})$ and $200^{\circ} \mathrm{C}(15 \mathrm{bar})$ for $10 \mathrm{~min}$. Ultrasound was applied as combination method after acid pretreatment. The condition during ultrasound treatment was $40 \mathrm{~W}$ at $50^{\circ} \mathrm{C}$ and $10 \mathrm{~min}$. Finally the pretreated sample was fermented using Saccharomyces cerevisiae yeast and the amount of produced ethanol was measured. Results: Acid treatment at $121^{\circ} \mathrm{C}, 15 \mathrm{~min}$ is an effective pretreatment method for converting lignocellulose to sugar. Up to $21.45 \%$ sugar w/w could be measure after acid treatment. Combination of chemical pretreatment and subsequent enzyme treatment increased the sugar yield drastically. Up to 37 and $28 \%$ sugar w/w could be achieved for acid and alkali pretreated samples respectively. Subcritical Water (SCW) treatment method is an effective physical method. SCW treatment at $200^{\circ} \mathrm{C}$ and 10 min followed by enzyme treatment yielded up to $17 \%$ sugar w/w. Combination of acid pretreatment with ultrasonic before enzyme treatment increased the conversion of lignocelluloses to sugar. Sugar yield up to $44 \% \mathrm{w} / \mathrm{w}$ after combination of acid and ultrasonic pretreatment and subsequent enzyme treatment could be achieved. Fermentation of pretreated rice straw shown that after 3 days fermentation most of sugar (55-65\%) will be converted to bioethanol. The remaining sugar could not be converted in ethanol even after 6 days fermentation. Under these conditions, the maximum ethanol of $1.69 \%(\mathrm{v} / \mathrm{v})$ was obtained. Conclusion: The combination method of acid pretreatment combined with ultrasound and subsequent enzyme treatment result the highest conversion of lignocelluse in rice straw to sugar and consequently, highest ethanol concentration after 6 days fermentation with S. cerevisae yeast.
\end{abstract}

Key words: Rice straw, bio ethanol, subcritical water, ultrasound, sugar, enzymes

\section{INTRODUCTION}

Ethanol from renewable resources has been of interest in recent decades as an alternative fuel to the current fossil fuels. Lignocelluloses biomass like wood and agricultural crops residue, e.g., straw and sugarbeet pulp are potential raw materials for producing several high-value products like fuel ethanol and biodiesel. Up to $80 \%$ of the lignocelluloses is polysaccharides (Kaparaju et al., 2009). These renewable raw materials look promising for replacing environmentally unfriendly fossil hydrocarbon raw materials and hence, creating "green" products. In contrast to traditional fuels, fermentation ethanol does not contribute to the greenhouse effect, being a $\mathrm{CO}_{2}$ neutral resource.
Rice straw is a by-product of rice production and great bio resource. It is one of the abundant lignocellulosic waste materials in the world. It is annually produced about 731 million tons, which is distributed in Africa 20.9 million tons, Asia 667.6 million tons and Europe 3.9 million. Rice straw can potentially produce 205 billion liters bioethanol per year, which is about 5\% of total of consumption. It is the largest amount from a single biomass feedstock. Rice straw predominantly contains cellulose $32-47 \%$, hemicelluloses $19-27 \%$ and lignin $5-24 \%$, ashes $18.8 \%$. The pentoses are dominant in hemicelluloses which xylose is the most important sugar followed by arabinose and hexoses. The carbohydrate of rice straw involves glucose $41-43.4 \%$, xylose $14.8-20.2 \%$, arabinose $2.7-4.5 \%$, mannose $1.8 \%$

Corresponding Author: Nutawan Yoswathana, Department of Chemical Engineering, Faculty of Engineering, Mahidol University, Thailand 
Energy Rec. J. 1 (1): 26-31, 2010

and galactose $0.4 \%$ (Maiorella, 1985; Roberto et al., 2003).

Several pre-treatment processes have been developed for lignocelluloses, which function by an enlargement of the inner surface area. This is accomplished partly by solubilization of the hemicelluloses and partly by degradation of the lignin. The pre-treatments are: Milling and grinding, pyrolysis, high-energy radiation, high pressure steaming, alkaline or acid hydrolysis, gas treatment (chlorine dioxide, nitrogen dioxide, sulfur dioxide, ozone), hydrogen peroxide treatment, organic solvent treatment, hydrothermal treatment, steam explosion, wet oxidation and biological treatment (Fan et al., 1982; Hormeyer et al., 1988; McGinnis et al., 1988).

Subcritical Water (SCW) treatment is an environmentally friendly "green" technique with wide range of application, such as extraction, hydrolysis and wet oxidation of organic compound (Holliday et al., 1998; Kruse and Dinjus, 2007). Thus, SCW can be used for extraction of organic compound instead of using organic solvent which are environmentally unacceptable. On the other hand, SCW has been widely used for hydrolysis of organic compounds. Recently growing attention has led to extensive research activities using SCW for hydrolysis and conversion of biomass and carbohydrates to useful compound.

There is no information available in literature about the combination of ultrasound as pretreatment and enzymatic conversion of lignocellulose to sugar.

The aim of this study is to investigate the effect of combined physical and chemical methods as pretreatment on conversion of lignocellulose in rice straw to sugar and fermentation of sugar to bioethanol using $S$. cerevisae yeast.

\section{MATERIALS AND METHODS}

Raw material: Rice Straw from Suphanburi province As enzyme mixture were 5 following technical enzyme cellulase/hemicellulase applied:

- Crystalzyme 200XL (valley Research, USA)

- Celluclast 1.5 LFG (Novozymes, Denmark)

- Alcalase 2.5 LDX (Novozymes, Denmark)

- Validase ANC-L (valley Research, USA)

- Xylanase (Dr. Luca and Partner Ingenieurkontor GmbH, Germany)

- The enzymes were mixed together in equal relation
Methods:

Alkali pre-treatment: About $50 \mathrm{~g}$ Chopped $(\approx 2 \mathrm{~cm}$ length) dried rice straw was suspended in 1, 2, 3, 4, 5\% $\mathrm{NaOH}$ in ratio of $1: 10(\mathrm{w} / \mathrm{v})$ rice straw and $\mathrm{NaOH}$. After that the samples were incubated in water bath $85^{\circ} \mathrm{C}$ for $1 \mathrm{~h}$. Finally, hydrolysate was pressed through cheese cloth. The amount of reducing sugar in juice was measured by using Luff schoorl method (Matissek and Steiner, 2006).

Acid pretreatment: About $50 \mathrm{~g}$ Chopped dried rice straw was suspended in acid solution (1, 3, 5, 7 and 9\% Sulfuric acid) in ratio of $1: 10(\mathrm{w} / \mathrm{v})$ rice straw and Sulfuric acid. The mixtures were autoclaved at $121^{\circ} \mathrm{C}$ for $15 \mathrm{~min}$. After that, hydrolysate was pressed through cheese cloth and the amount of reducing sugar in juice was measured as above.

Alkali/enzyme pre-treatment: The best alkali pretreatment condition was carried out for Alkali/Enzyme pre-treatment. The $\mathrm{NaOH}$ treated sample was pressed through cheese cloth. The juice was kept and the remaining pulp was mixed with distilled water (10:1 w/w on rice straw basis) containing enzyme mixture $(0.8 \% \mathrm{v} / \mathrm{w}$ on of rice straw basis). The $\mathrm{pH}$ of sample was adjusted at $\mathrm{pH}=4$. Sample was incubated in a water bath at $55^{\circ} \mathrm{C}$ for $12 \mathrm{~h}$ (1st Enzyme). After that the sample was pressed through cheese cloth and the pulps of these pressed sample was applied for second enzymatic treatment as described above (2nd Enzyme). The juice of first press as well as "1st Enzyme" and "2nd Enzyme" were carried out for sugar content measurement.

Acid/enzyme pretreatment: The best acid pretreatment condition was chosen for acid/enzyme pretreatment. For enzymatic hydrolysis the sample were treated as described in alkali/enzyme pretreatment.

Subcritical water pre-treatment: For Subcritical Water (SCW) treatment a high pressure tube $(\varnothing=15 \mathrm{~mm}$. Volume $=80 \mathrm{~mL})$ equipped with pressure gauge and thermocouple was used. The heating of SCW tube was carried out in oil bath at constant temperature.

Chopped dried rice straw was mixed with distilled water in ratio $1: 10(\mathrm{w} / \mathrm{v})$ rice straw and water. The mixture was poured in subcritical water tube and the experiment conducted at 160 and $200^{\circ} \mathrm{C}$ for $10 \mathrm{~min}$. in oil bath. After subcritical water treatment, the tube was cooled in water bath and the content was poured in a beaker. Subsequently, the samples were treated with enzyme mixture $(0.8 \%$ v/w on rice straw basis, $\mathrm{pH}=$ 4.0) for $12 \mathrm{~h}$ at $55^{\circ} \mathrm{C}$. The samples were then pressed 
through cheese cloth and the sugar content in pressed liquid was measured.

Ultrasonic pretreatment: Acid pre-treated (1\% acid) sample was placed in a beaker and treated with ultrasonic at $40 \mathrm{~W}$ for $10 \mathrm{~min}$. The temperature during ultrasonic treatment was $<50^{\circ} \mathrm{C}$. After ultrasonic treatment the sample was subjected to enzyme $(4.0 \%$ $\mathrm{v} / \mathrm{w}$ on rice straw basis, $\mathrm{pH}=4.0)$ treatment. The sample was pressed through cheese cloth and the amount of sample was measured.

Detoxification: The pretreated samples from acid/enzyme pretreatment and ultrasound pretreatment was mixed with wood activated charcoal (20:1 w/w sample: Charcoal) and then agitate for 2 days on magnetic stirrer at room temperature. After charcoal treatment the sample was filtered using filter No. 5 (Whatman, Germany) to remove the charcoal. The filtrate was subjected for sugar measurement.

Fermentation: The pretreated samples from acid/enzyme pretreatment and ultrasound pretreatment with or without detoxification were carried out for fermentation experiments.

The yeast $S$. cerevisae was used for fermentation. The initial yeast count in fermentation sample was 2$8 \times 10^{8} \mathrm{cfu} \mathrm{mL}^{-1}$. After 3 and 6 fermentation days the ethanol content was measured by gas chromatography. In addition the remaining sugar during fermentation was measured.

For calculation of ethanol yield the following equation was applied:

$$
\text { Ethanol.Yield }=\frac{\text { Measured.Ethanol.in.Sample }(\mathrm{g})}{\text { Theoretical.Ethanol }(\mathrm{g})}
$$

Theoretical ethanol $(\mathrm{g})=$ Amount of initial sugar content $(\mathrm{g})$ in fermentation solution $\times 0.5$

All the measurements were duplicated and the data reported are average of two replications.

\section{RESULTS}

Effect of acid pre-treatment methods on sugar content: In the Fig. 1 the relation between sugar content and acid concentration is illustrated. Increasing the acid concentration showed reverse effect on sugar concentration in sample. This is maybe because of degradation of monomeric sugars (xylose, glucose) in furfural and hydroxymethyl furfural. The highest sugar up to $21.45 \%$ sugar (on the rice straw basis) could be obtained using $1 \%$ sulfuric acid.

Effect of alkali pre-treatment methods on sugar content: Higher concentration of alkali leads to slight increasing the sugar in sample (Fig. 2). Generally, very low sugar content of $\leq 0.55 \%$ (on the rice straw basis) could be observed.

Effect of acid and alkali pre-treatment and subsequent enzyme treatment on sugar content: Application of technical enzymes have positive effect on conversion of lignocellulose material to sugar. This was observed for acid pretreated as well as alkali pretreated samples (Fig. 3).

The sugar yield was in acid pretreated and subsequent enzyme treated sample distinct higher (36.95\%) compare to only acid pretreated sample $(21.45 \%)$. Whereas, nearly no effect of alkali pretreatment on conversion of cellulose and hemicelluloses to glucose could be observed, a drastically increase of sugar concentration $(24.6 \%$ on rice straw basis) in alkali pretreated and subsequent enzyme treated sample could be achieved.

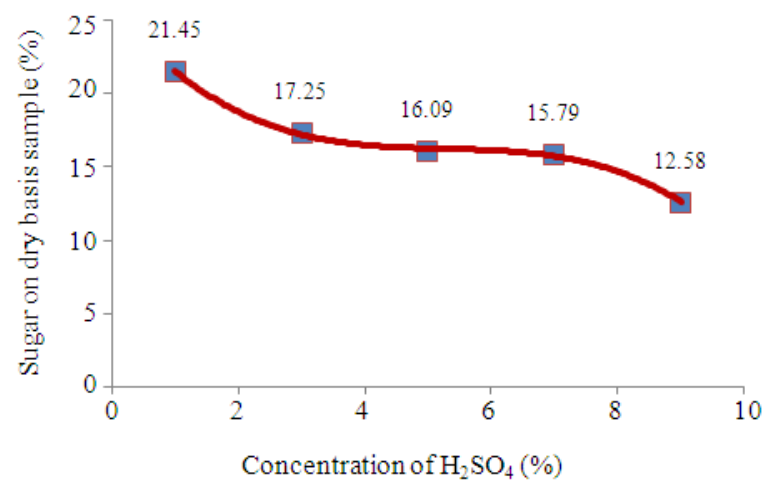

Fig. 1: Sugar content in acid pre-treated rice straw

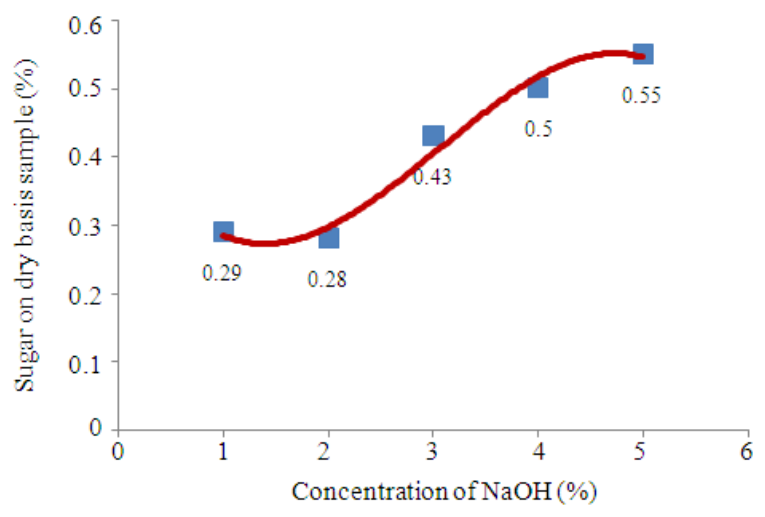

Fig. 2: Sugar content in alkali pretreated rice straw 
Energy Rec. J. 1 (1): 26-31, 2010

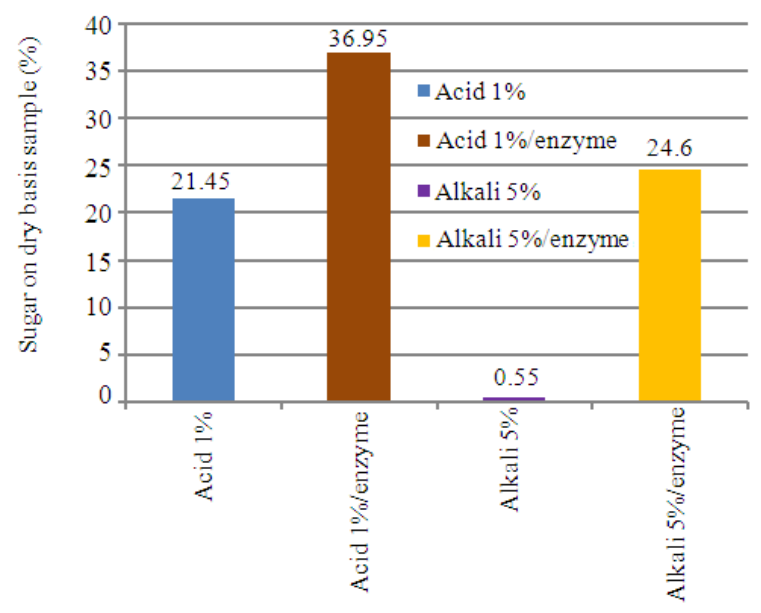

Fig. 3: Effect of acid and alkali pretreatment with or without subsequent enzyme treatment to sugar content of rice straw

Table 1: Sugar content of Subcritical Water (SCW) pretreatment and subsequent enzyme treated rice straw

\begin{tabular}{llc}
\hline Condition & Temperature $\left({ }^{\circ} \mathrm{C}\right)$ & Percentage of sugar* \\
\hline SCW/enzyme & 160 & 7.4 \\
& 200 & 16.9 \\
Only enzyme & 30 & 3.4 \\
\hline
\end{tabular}

*: On rice straw basis

Table 2: Lignocellulose conversion to sugar and sugar yield of different treated rice straw

\begin{tabular}{lc}
\hline Pretreatment & Sugar $(\%) *$ \\
\hline Acid $1 \%$ & 21.45 \\
Acid $1 \% /$ enzyme $(0.8 \% \mathrm{v} / \mathrm{w})$ & 36.95 \\
Acid $1 \% /$ enzyme $(4 \% \mathrm{v} / \mathrm{w})$ & 39.10 \\
Alkali $5 \%$ & 0.55 \\
Alkali $5 \% / \mathrm{enzyme}(0.8 \% \mathrm{v} / \mathrm{w})$ & 24.60 \\
SCW/enzyme, $(0.8 \% \mathrm{v} / \mathrm{w})$ & 16.90 \\
Enzyme, $(0.8 \% \mathrm{v} / \mathrm{w})$ & 3.40 \\
Acid $1 \%+$ ultrasonic + enzyme $(4 \% \mathrm{v} / \mathrm{w})$ & 43.93 \\
Acid $1 \%+$ ultrasonic + enzyme $(4 \% \mathrm{v} / \mathrm{w} /$ and detoxified $)$ & 32.29 \\
\hline *: On rice straw basis
\end{tabular}

In contrast enzyme treatment of sample without pretreatment have nearly no effect (3.4\% sugar on rice straw basis) on sugar content of rice straw.

Effect of subcritical water treatment: Table 1 shown the effect of subcritical water and subsequent enzyme treatment on conversion of lignocelluloses to sugar. Increasing the temperature during SCW from 160$200^{\circ} \mathrm{C}$ increased the sugar concentration more than 2 times (from 7.4-17\% sugar on rice straw basis).

Effect of enzyme concentration: Increasing the enzyme concentration from $0.8 \mathrm{v} / \mathrm{w}$ (on rice straw basis) to $4 \% \mathrm{v} / \mathrm{w}$ lead to increasing of sugar in acid pretreated sample from 36.96 to $39.10 \%$ respectively (Table 2).

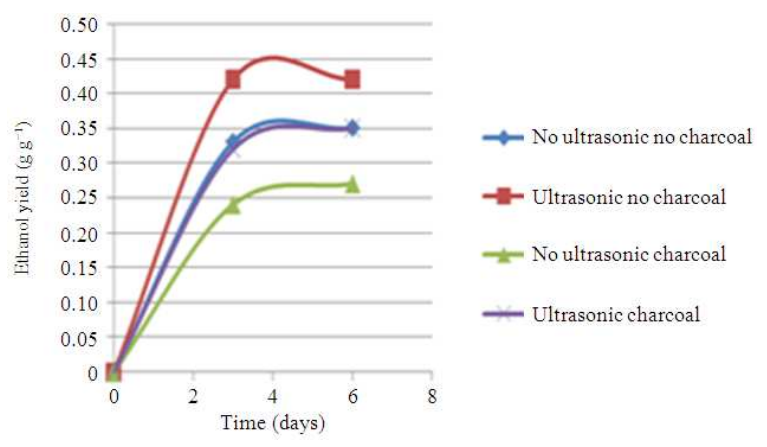

Fig. 4: Ethanol yield during fermentation

Table 3: Sugar concentration (g/100 g solution) during fermentation

\begin{tabular}{lllll}
\hline Fermentation time (day) & $\mathrm{A}$ & $\mathrm{B}$ & $\mathrm{C}$ & $\mathrm{D}$ \\
\hline 0 & 4.35 & 5.13 & 4.02 & 4.49 \\
3 & 2.00 & 2.13 & 1.67 & 1.98 \\
6 & 1.60 & 1.77 & 1.51 & 1.75 \\
\hline
\end{tabular}

Note: $\mathrm{A}=$ No ultrasonic/No detoxification; $\mathrm{B}=$ With ultrasonic/No detoxification; $\mathrm{C}=$ No ultrasonic/with detoxification; $\mathrm{D}=$ With ultrasonic/with detoxification

Effect of combined Ultrasonic (US) and acid pretreatment on sugar content: The sugar content of combined acid and ultrasonic pretreated and subsequent enzyme ( $4 \% \mathrm{v} / \mathrm{w}$ on rice straw basis) treated sample was higher (43.93\% sugar on rice straw basis) compare to sample without ultrasonic treatment $(39.1 \%)$ (Table 2). This results show the positive effect of ultrasonic treatment during pretreatment of rice straw on polysaccharide conversion into sugar.

Effect of Detoxification on sugar content: During detoxification of samples part of sugar could be adsorbed on activated charcoal leading reduction of total sugar in sample. In Table 2 is the amount of sugar before and after charcoal treatment illustrated.

Fermentation: Figure 4 show the effect of fermentation time on conversion of sugar to ethanol in acid pretreated, with or without ultrasonic and subsequent enzyme treated rice straw. During 3 days fermentation time nearly all for $S$. cerevisae fermentable sugar (glucose) will be converted to bioethanol. Longer fermentation time up to 6 days have only slight effect on bioethanol production. The sugar concentration in sample decreased from $4-5 \% \mathrm{w} / \mathrm{v}$ to nearly $1.5 \% \mathrm{w} / \mathrm{v}$ after 6 days fermentation. This is equal to $55-65 \%$ bioconversion of sugar to bioethanol (Table 3).

The ethanol yield in this study was about $0.42 \mathrm{~g} \mathrm{~g}^{-1}$ (Fig. 4). 


\section{DISCUSSION}

The decrease of sugar content in acid treated samples with increasing of acid concentration is may be because of degradation of monomeric sugars (xylose, glucose) in furfural and hydroxymethyl furfural. These substances are toxic substances for yeast and can inhibit the yeast growth.

The positive effect of acid pre-treatment and subsequent enzyme treatment could be explained as better access of enzyme to lignocellulose materials in rice straw. Vlasenko et al. (1997) have found that after acid pretreatment $\left(10 \%\right.$ solid mater, $0.8 \%$ acid, $\left.160^{\circ} \mathrm{C}\right)$ followed by enzyme treatment (cellulose $100 \mathrm{~L}+$ cellubiase) the yield of glucose was $43 \mathrm{~g} \mathrm{~L}^{-1}$ or $43 \%$ conversion of cellulose to glucose. The results in present study is slightly less than Valsenko et al. (1997) reported. This is may be due to lowe temperature $\left(121^{\circ} \mathrm{C}\right.$ compare to $\left.160^{\circ} \mathrm{C}\right)$ during acid treatment or because of different conditions during enzyme treatment.

There was clear relationship between temperature during SCW and effectiveness of this "green technology". Increasing the temperature and pressure during SCW treatment indicated higher conversion of lignocellulose to sugar after subsequent enzyme treatment. Karimi et al. (2006) reported the conversion of rice straw to sugar by $\mathrm{SCW}$. SCW treatment at 15 bar and $200^{\circ} \mathrm{C}$ without adding acid resulted $9.9 \%$ sugar (glucose and xylose) after 2 times SCW treatment. Bobleter and Bonn (1983) found out that hemicellulose sould be completely separated from the lignocellulose and enzymatic digestability of cellulose can be significantly increased by treating the lignocellulose material with SCW in flow through system.

Power ultrasound produce cavitations. Cavitations can break down cell structure and cell polymers (such as cellulose, hemicellulose) structures. Combined acid pre-treatment and ultrasonic followed by enzyme treatment resulted highest sugar yield up to $44 \%$ (on rice straw basis). This results show the effectiveness of combination of physical and chemical pre-treatment prior to enzymatic hydrolysis of lignocellulose material to sugar.

Detoxification of samples prior to fermentation showed no positive effect on ethanol yield. It could be postulated that the concentration of phenolic substances after acid treatment was less and had nearly no effect on S. cerevisae growth.

Abedinfar et al. (2009) have investigated the fermentation of rice straw (pretreated with diluted acid and subsequent enzyme treatment) rice straw using Mucor indicus and Rhizopus oryzae. They have found an ethanol yield of 0.36-0.43 $\mathrm{g} \mathrm{g}^{-1}$ using Mucor indicus which was comparable with the corresponding yield by S. cerevisae (0.37-0.45). Rhizopus oryzae produce 0.33 $0.41 \mathrm{~g} \mathrm{~g}^{-1}$ ethanol.

The ethanol yield in this study was about $0.42 \mathrm{~g} \mathrm{~g}^{-1}$. That is in accordance with ethanol yield reported from literature (Abedinfar et al., 2009).

The remaining sugar of $35-45 \% \mathrm{w} / \mathrm{v}$ is may be xylose. Xylose is pentose sugar that can not be digested by $S$. cerevisae.

\section{CONCLUSION}

The comparison between different chemical pretreatment methods has shown that the acid treatment combined with subsequent enzyme treatment is a suitable method for conversion of lignocellulose to sugar. Up to $36 \%$ sugar could be observed after this method. Combination of acid pretreatment and ultrasonic before enzyme treatment lead to much higher sugar up to $44 \%$. Detoxification of sample before fermentation showed decrease of sugar concentration on sample upon absorption of sugar on activated charcoal.

It should be noted, that the ethanol concentration achieved in this study was not higher than $15 \mathrm{~g} \mathrm{~L}^{-1}$ as a consequence of low rice straw loading. Therefore, in order to achieve higher concentration of ethanol attractive for industrial application, higher rice straw loading is necessary.

\section{ACKNOWLEDGEMENT}

We would like to thank Mahidol University for financial support of this project.

\section{REFERENCES}

Abedinfar, S., K. Karimi, M. Khananhmadi and M. Taherzadeh, 2009. Ethanol production by Mucor indicus and Rhizopus oryzae from rice straw by separate hydrolysis and fermentation. Biomass Bioenergy, 33 : $828-833 . \quad$ DOI: 10.1016/j.biombioe.2009.01.003

Bobleter, O. and G. Bonn, 1983. Hydrothermolysis of biomass-production of raw material for alcohol fermentation and other motor fuels. Alter. Energy Sour., 3: 323-332. DOI: 10.1016/00086215(83) 884547

Fan, L.T., Y.H. Lee and M.M. Gharpuray, 1982. The nature of lignocellulosics and their pretreatments for enzymatic hydrolysis. Adv. Biochem. Eng., 23: 157-187. DOI: 10.1007/3-540-11698-2 
Holliday, R.L., Y.M. Jong and J.W. Kolis, 1998. Organic synthesis in subcritical water: Oxidation of alkyl aromatics. J. Supercritic. Fluid, 12: 255-260. DOI: 10.1016/S0896-8446(98)000849

Hormeyer, H.F., W. Schwals, G. Bonn and O. Bobleter, 1988. Hydrothermolysis of birchwood as pretreatment for enzymatic saccharification. Holzforschung, 42: 96-98. DOI: 10.1515/hfsg.1988.42.295//1988

Kaparaju, P., M. Serrano, A.B. Thansen, P. Kongian and I. Angelidai, 2009. Bioethanol, biohydrogen and biogas production from wheat straw in a biorefinery concept. Bioresour. Technol., 100: 2562-2568. DOI: 10.1016/j.biortech.2008.11.011

Karimi, K., S. Kheradmandinia and M.J. Taherzadeh, 2006. Conversion of rice straw to sugar by diluteacid hydrolysis. Biomass Bioenergy, 30: 247-253. DOI: 10.1016/j.biombioe.2005.11.015

Kruse, A. and E. Dinjus, 2007. Hot compressed water as reaction medium and reactant properties and synthesis reactions. J. Supercritic. Fluids, 39: 362-380. DOI: 10.1016/j.supflu.2006.03.016

Maiorella, B.L., 1985. Ethanol. In: Comprehensive Biotechnology, Young, M. (Ed.). Pergamon Press, Oxford, ISBN: 0080325122, pp: 861-914.
Matissek, R. and G. Steiner, 2006. Lebensmittel Analytik: Grundzuge, Methoden, Anwendungen. Speringer-Verlag, ISBN: 978-3-540-62513-1.

McGinnis, G.D., W.W. Wilson, S.E. prince and C.C. Cheng, 1983. Conversion of biomass into chemicals with high-temperature wet oxidation. Ind. Eng. Chem. Prod. Res. Dev., 22: 633-639. DOI: 101021/i300012a22

Roberto, I.C., S.I. Mussatto and R.C.L.B. Rodrigues, 2003. Dilute-acid hydrolysis for optimization of xylose recovery from rice straw in a semi-pilot reactor. Ind. Crops Prod., 7: 171-176. DOI: 10.1016/S0926-6690(02)00095-X

Vlasenko, E.Y., H. Ding, J.M. Labavitch and S.P. Shoemaker, 1997. Enzymatic hydrolysis of pretreated rice straw. Califor. Inst. Food Agric. Res., 59: 109-119. DOI: 10.1016/S0960852(96)00169-1 